\title{
Peningkatan Keaktifan Siswa melalui Penerapan Model Mind Mapping pada Siswa SD Kelas IV Sekolah Dasar
}

\author{
Wiwik Setiayu \\ Universitas Sebelas Maret \\ setiayuh@gmail.com
}

\section{Article History}

received 30/4/2021

\begin{abstract}
This study aims to increase the activiness of 4' grade students through the Mind Mapping learning model. The problems of this study are (1) students are not so capable to involve themselves in question and answer process in the group (2) the low level of learning material (3) students tend to be passive in learning process. The research was conducted using the CAR (Classroom Action Research) Hopkins (1993) method with four stages which is carried out in two cycles. The target in this study was all fourth grade students. The results of the research obtained indicate that the Mind Mapping learning model can improve of students activities. This is evidenced by an increase in the second cycle of $26 \%$ with the acquisition of students activities, namely 92\%. This shows activities that students have $80 \%$.
\end{abstract}

Keywords: students activity, Mind Mapping learning model.

\section{Abstrak}

Penelitian ini bertujuan untuk meningkatkan keaktifan siswa kelas IV melalui model pembelajaran Mind Mapping. Permasalahan dari penelitian ini adalah (1) Siswa kurang mampu melibatkan diri dalam proses tanya jawab dalam kelompok. (2) Rendahnya tingkat penguasaan materi pembelajaran. (3) Siswa cenderung pasif dalam pembelajaran. Penelitian dilakukan menggunakan metode PTK (Penelitian Tindakan Kelas) Hopkins (1993) dengan 4 tahapan yang dilaksanakan dengan dua siklus. Sasaran dalam penelitian ini adalah semua siswa kelas IV. Hasil dari penelitian yang didapatkan menunjukkan bahwa model pembelajaran Mind Mapping dapat meningkatkan keaktifan siswa. Hal ini dibuktikan dengan adanya peningkatan pada siklus II sebesar $26 \%$ dengan perolehan persentase keaktifan siswa yaitu $92 \%$. Hal ini menunjukkan bahwa keaktifan siswa secara klasikal sudah $\geq 80 \%$.

Kata kunci: keaktifan siswa, model pembelajaran Mind Mapping. 


\section{PENDAHULUAN}

Tujuan pendidikan nasional adalah menjamin mutu pendidikan nasional dalam rangka mencerdaskan kehidupan bangsa dan membentuk watak serta peradaban bangsa yang bermartabat (PP No. 19 tahun 2005). Salah satu perwujudannya melalui pendidikan bermutu pada setiap satuan pendidikan di Indonesia.

Perwujudan pendidikan bermutu tidak hanya dilihat dari hasil belajar siswa, namun proses pembelajaran penting untuk menjadikan generasi yang kreatif dan kompetitif. Tingkat keberhasilan guru pada saat mengajar dapat dilihat dari keberhasilan siswanya sehingga dikatakan bahwa guru yang hebat adalah guru yang dapat menciptakan pembelajaran yang inovatif dan pembelajaran yang kreatif bagi siswanya. Kualitas pembelajaran dilihat dari kreatifitas yang dapat dilakukan oleh siswa setelah mengikuti pembelajaran dan aktivitas siswa ketika belajar (Gultom, 2013).

Berdasarkan hasil wawancara peneliti dengan guru kelas IV SD Negeri 2 Bener pada tanggal 2 Februari 2021 kendala yang dialami guru dalam proses pembelajaran adalah (1) kurangnya keaktifan siswa dalam mengikuti pembelajaran. (2) Siswa cenderung pasif dalam pembelajaran. (3) Siswa kurang mampu melibatkan diri dalam proses tanya jawab dalam kelas. (4) Kurangnya kerjasama dengan teman lainnya. (5) Rendahnya tingkat penguasaan siswa terhadap materi pembelajaran Salah satu model pembelajaran yang dapat meningkatan keaktifan belajar siswa tersebut adalah model pembelajaran Mind Mapping.

Salah satu model pembelajaran yang dapat meningkatan keaktifan belajar siswa tersebut adalah model pembelajaran Mind Mapping. Mind mapping merupakan cara mencatat yang kreatif dan efektif bagi siswa untuk menempatkan informasi ke dalam otak dan mengambil informasi ke luar dari otak (Puspita 2012).

Menurut Mustari \& Irianto (2016) menarik kesimpulan bahwa aktivitas belajar siswa mengalami peningkatan pada pembelajaran. Hal tersebut ditunjukan dengan meningkatnya aktivitas siswa ketika diskusi kelompok, yaitu pada saat mengemukakan pendapat dan kerjasama.

Berdasarkan latar belakang masalah di atas maka peneliti tertarik untuk melakukan penelitian lebih mendalam tentang "Peningkatan Keaktifan Siswa Melalui Penerapan Model Pembelajaran Mind Mapping pada Kelas IV SD Negeri 2 Bener Tahun Pelajaran 2020/2021".

\section{METODE}

Metode yang digunakan pada penelitian ini adalah Penelitian Tindakan Kelas (PTK) model Kemmis \& Taggart (dalam Arikunto, 2013:138-140) yang dilaksanakan dalam 2 siklus yaitu siklus I dan siklus II yang masing dilakukan dalam setiap siklus terdiri dari perencanaan, tindakan dan observasi serta refleksi (Suharsimi; 2007:107). Pelaksanaan penelitian ini dilaksanakan pada siswa kelas IV SD Negeri 2 Bener yang berjumlah 20 siswa yang terdiri dari 8 siswa laki-laki dan 12 siswa perempuan.

Data hasil penelitian berupa data kualitatif yang bersumber pada keaktifan siswa dalam mengikuti kegiatan pembelajaran. Adapun teknik pengumpulan datanya adalah dengan menggunakan lembar observasi keaktifan siswa

Indikator proses yang merupakan aktivitas dalam pembelajaran dikategorikan terlaksana dengan baik jika minimal $80 \%$ dari indikator langkah-langkah model Mind Mapping terlaksana dan minimal $80 \%$ langkah-langkah model Mind Mapping yang dikategorikan sebagai aspek yang diamati berada dalam kategori baik. Pengukuran penerapan aktivitas mengajar guru dan belajar siswa tersebut didasarkan pada pengkategorian skala tiga yang mengacu pada standar Zain, A, dkk (2013: 107). 


\section{HASIL DAN PEMBAHASAN}

Penelitian Tindakan Kelas ini dilakukan melalui 2 siklus yaitu siklus I dan siklus II yang mengacu pada model Kemmis \& Mc Taggart ada beberapa tahapan dalam penelitian ini, yaitu: (1) perencanaan, (2) pelaksanaan, (3) pengamatan, (4) refleksi yang dilakukan pada siswa kelas IV SDN 2 Bener. Penelitian ini menerapkan model Mind Mapping untuk meningkatkan keaktifan siswa dalam pembelajaran di kelas sehingga aktivitas dalam pembelajaran dikategorikan terlaksana dengan baik jika minimal 80\% dari indikator langkah-langkah model Mind Mapping terlaksana

Dari hasil penerapan model Mind Mapping untuk meningkatkan keaktifan siswa dalam pembelajaran di kelas maka didapatkan hasil data pada siklus I dan siklus II adalah sebagai berikut :

Tabel 1. Hasil Pengamatan Lembar Observasi PTK

\begin{tabular}{lcc}
\hline \multicolumn{1}{c}{ Aspek } & $\begin{array}{c}\text { Siklus I } \\
(\%)\end{array}$ & $\begin{array}{c}\text { Siklus II } \\
(\%)\end{array}$ \\
\hline Aktivitas Guru & $80 \%$ & $93 \%$ \\
Aktivitas Siswa & $86,67 \%$ & $93 \%$ \\
Keaktifan & $66 \%$ & $92 \%$ \\
\hline
\end{tabular}

Dari tabel di atas dapat dilihat bahwa pada siklus I model pembelajaran Mind Mapping sudah diterapkan, dapat disimpulkan bahwa persentase pencapaian penerapan model Mind Mapping oleh guru adalah 80\%, dengan kategori baik (B), aktivitas peserta didik selama penerapan model Mind Mapping adalah 86, 67\%, dengan kategori baik (B) secara kumulatif. Adapun untuk setiap aspek yang diamati, terdapat tiga aspek pengamatan yang berada pada kategori baik (B) dan dua aspek pengamatan yang berada dalam kategori cukup (C). Sedangkan persentase pencapaian perkembangan keaktifan peserta didik selama penerapan model Mind Mapping oleh guru adalah 66\%, dimana indikator keaktifan peserta didik dalam pembelajaran dikategorikan terlaksana dengan baik jika minimal $80 \%$, dapat disimpulkan bahwa capaian hasil untuk perkembangan keaktifan peserta didik, tidak mencapai indikator keberhasilan yang telah ditetapkan. Berdasarkan hal tersebut, diperlukan pengkajian mendalam terkait hal-hal yang perlu diperkuat maupun diperbaiki untuk meningkatkan kualitas proses pembelajaran saat pelaksanaan siklus II.

Pada siklus II berdasarkan refleksi pada siklus I ternyata indikator keaktifan peserta didik, tidak mencapai indikator keberhasilan yang telah ditetapkan oleh sebab itu maka penelitian dilanjutkan dengan tetap model pembelajaran Mind Mapping tetapi dengan ditunjang dengan metode atau aspek yang lain. Data yang dihasilkan adalah lembar observasi keaktifan siswa pada siklus II mengalami peningkatan dan perkembangan dibandingkan pada siklus I. Pencapaian aktivitas guru pada siklus I mencapai $80 \% \%$ dan pada siklus II meningkat menjadi 93\%. Pencapaian aktivitas siswa pada siklus I mencapai $86,67 \% \%$ dan pada siklus II meningkat menjadi $93 \%$. Pencapaian keaktifan siswa pada siklus I mencapai $66 \%$ dan pada siklus II meningkat menjadi $92 \% \%$. Dari data yang didapatkan sudah menunjukkan peningkatan dan sudah menunjukkan hasil yang termasuk sangat memuaskan, karena sudah mencapai indikator keberhasilan klasikal yang telah ditetapkan yaitu indikator keaktifan peserta didik dalam pembelajaran dikategorikan terlaksana dengan baik jika minimal $80 \%$.

Di bawah ini disajikan sebuah diagram peningkatan keaktifan siswa kelas IV dari siklus I dan siklus II yang lebih jelas: 
Volume 9 Nomor 1 Tahun 2021

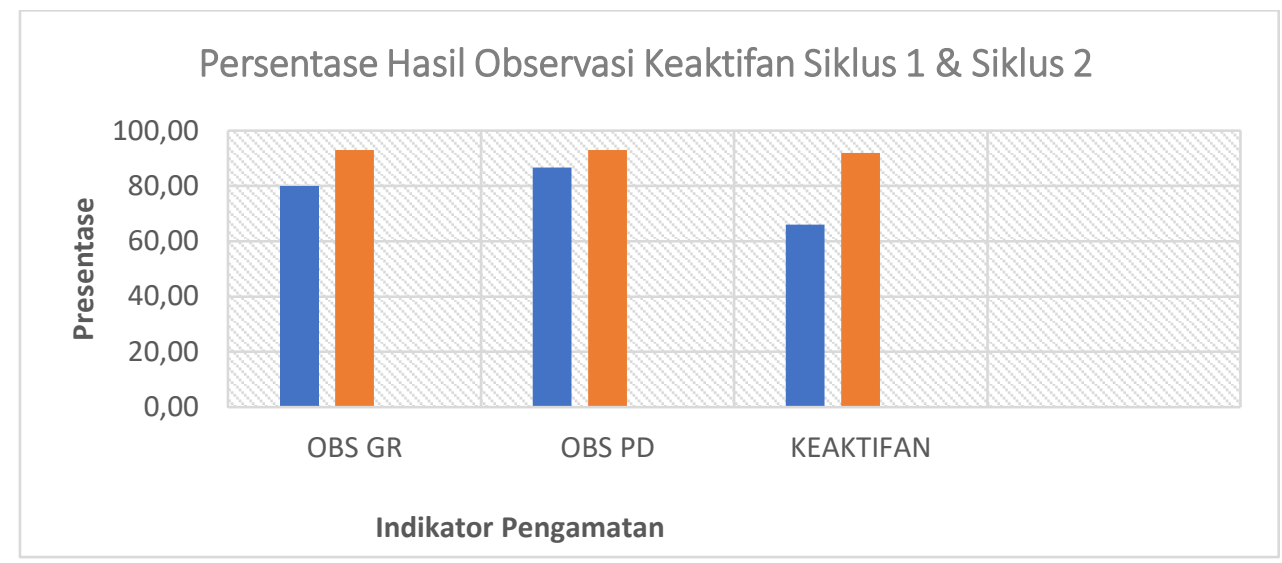

Gambar 1. Rekapitulasi Keaktifan Siswa Kelas IV

Berdasarkan data tersebut maka dapat diketahui bahwa pelaksanaan PTK dengan menerapkan model Mind Mapping berhasil meningkatkan keaktifan siswa pada pembelajaran berpusat pada tema 4 subtema 3 pembelajaran 3 tematik mata pelajaran Bahasa Indonesia, dan PKn. Penerapan model Mind Mapping tampak memberikan perubahan yang positif dalam kegiatan belajar mengajar. Dampak positif tersebut terlihat dari peserta didik yang aktif, semangat, berani berbicara dan berpendapat dalam mengikuti kegiatan belajar mengajar. Hal tersebut sejalan dengan penelitian yang dilakukan oleh Puspita 2012 bahwa model Mind Mapping merupakan cara mencatat yang kreatif dan efektif bagi siswa untuk menempatkan informasi ke dalam otak dan mengambil informasi ke luar dari otak .

Berdasarkan data tersebut dapat diketahui bahwa model pembelajaran Mind Mapping terbukti dapat meningkatkan hasil keaktifan siswa di kelas IV SD Negeri 2 Bener Kecamatan Wonosari Kabupaten Klaten Tahun Pelajaran 2020/2021.

\section{SIMPULAN}

Berdasarkan hasil penelitian tindakan kelas yang dilakukan di SD Negeri 2 Bener Kecamatan Wonosari Kabupaten Klaten Tahun Pelajaran 2020/2021, dapat disimpulkan bahwa penerapan model pembelajaran Mind Mapping terbukti dapat meningkatkan hasil keaktifan siswa kelas IV SD Negeri 2 Bener. Hal ini dibuktikan dengan adanya peningkatan keaktifan siswa pada setiap siklusnya berdasarkan data yang dihasilkan adalah lembar observasi keaktifan siswa pada siklus II mengalami peningkatan dan perkembangan dibandingkan pada siklus I. Pencapaian aktivitas guru pada siklus I mencapai $80 \% \%$ dan pada siklus II meningkat menjadi $93 \%$. Pencapaian aktivitas siswa pada siklus I mencapai $86,67 \% \%$ dan pada siklus II meningkat menjadi $93 \%$. Pencapaian keaktifan siswa pada siklus I mencapai $66 \%$ dan pada siklus II meningkat menjadi $92 \% \%$. Dari data yang didapatkan sudah menunjukkan peningkatan dan sudah menunjukkan hasil yang termasuk sangat memuaskan, karena sudah mencapai indikator keberhasilan klasikal yang telah ditetapkan yaitu indikator keaktifan peserta didik dalam pembelajaran dikategorikan terlaksana dengan baik jika minimal $80 \%$. Indikator Keberhasilan secara klasikal dan individual sudah terpenuhi atau tercapai.

\section{DAFTAR PUSTAKA}

Buzan, T. (2012). Buku Pintar Mind Map. Jakarta: Gramedia.

Huda, F. A. (2018, Pebruari 21). Pengertian Keaktifan Belajar. Retrieved from Fatkhan.web.id: http://fatkhan.web.id/pengertian-keaktifan-belajar/ 
Isrok'atun, T. (2016). In Model Pembelajaran Matematika Situation-Based Learning di Sekolah Dasar. Bandung: UPI Sumedang Press.

Mahmudin. (2009). Retrieved from Pembelajaran Berbasis Peta Pikiran: http://Mahmudin. wordpress.com.

Manis, S. (2019, Maret 15). Pengertian PTK, Tujuan, Karakteristik, Prinsip, Langkah dan Model Penelitian Tindakan Kelas (PTK) Lengkap. Retrieved from Pelajaran.co.id: $\quad$ https://www.pelajaran.co.id/2019/15/pengertian-ptktujuankarakteristik-prinsip-langkah-dan-model-penelitian-tindakan-kelasptk.html

Mudjiono, D. d. (2009). Belajar \& Pembelajaran. In D. d. Cipta.. Jakarta: Rineka Cipta. Nisha, M. A. (2012). Tentang Mind Mapping. Retrieved from http://Miyazaki.blogspot. com.

Prastowo, A. (2013). Pengembangan Bahan Ajar Tematik. Yogyakarta: DVI Press.

Putranta, H. (2018). Model Pembelajaran Kelompok Sistem Perilaku: Behaviour System Group Learning Model. Yogyakarta: Himawan Putranta.

Riadi, M. (2020, Maret 6). Penelitian Tindakan Kelas. Retrieved from Kajian Pustaka.com: https://www.kajianpustaka.com/2019/03/penelitiantindakan-kelasptk.html

Sakdiyah, H. (2018). Penerapan Metode Mind Mapping dapat Meningkatkan Hasil Belajar Siswa Kelas VB MIN 10 Aceh Besar.

Sangaji, E. M. (2010). Metodologi Penelitian-Pendekatan Praktis dalam Penelitian. Yogyakarta: Andi.

Sani, R. A. (2013). Inovasi Pembelajaran. Jakarta: Bumi Aksara.

Sanjaya, W. (2010). Strategi Pembelajaran Berorientasi Standar Proses Pendidikan. Jakarta: Kencana.

Suyadi. (2015). Panduan Penelitian Tindakan Kelas. Yogyakarta: DVI Press.

Syah, M. (2004). Psikologi Pendidikan dengan Pendekatan Baru. Bandung: PT. Remaja Rosdakarya.

Zain, d. A. (2013). Strategi Belajar Mengajar. Jakarta: Rineka Cipta. 